\title{
EPSL
}

\section{Early Miocene anatexis identified in the western syntaxis, Pakistan Himalaya}

\author{
D.A. Schneider ${ }^{\text {a,* }}$, M.A. Edwards ${ }^{\text {b,1 }}$, W.S.F. Kidd ${ }^{\text {b }}$, P.K. Zeitler ${ }^{\text {a }}$, C.D. Coath ${ }^{\mathrm{c}}$ \\ ${ }^{a}$ Department of Earth and Environmental Sciences, Lehigh University, 31 Williams Drive, Bethlehem, PA 18015, USA \\ ${ }^{b}$ Department of Earth and Atmospheric Sciences, University at Albany, Albany, NY 12222, USA \\ ${ }^{c}$ Department of Earth and Space Sciences, University of California, Los Angeles, CA 90095, USA
}

Received 24 September 1998; revised version received 7 December 1998; accepted 13 January 1999

\begin{abstract}
Evidence for typical Himalayan Early to Middle Miocene anatexis has remained elusive in the Nanga Parbat massif in the western Himalaya of Pakistan; previous work has identified only young plutonism (10-1 Ma). New U-(Th)- $\mathrm{Pb}$ data from the Southern Chichi granite, a leucogranite in southern Nanga Parbat, reveal that crustal melting occurred during the Early Miocene. This largely undeformed, fine-grained pluton intrudes the Indian metasedimentary cover sequence adjacent to the Rupal shear, a major shear zone at Nanga Parbat. $\mathrm{Th}-\mathrm{Pb}$ ion microprobe analyses of monazites from the Chichi granite yield ages between $22 \mathrm{Ma}$ and $16 \mathrm{Ma}$, with the majority of analyses lying at 19-18 Ma. U/Pb zircon analyses yield ages which fall along a chord with a lower intercept age of $19 \mathrm{Ma}$. The zircons also contain an $1850 \mathrm{Ma}$ inherited component. These data indicate that the Early Miocene anatexis that is ubiquitous in central portions of the Himalayan orogen, unreported anywhere in the NW Himalaya, also occurred in the western Himalayan syntaxis, and demonstrates that Nanga Parbat has a protracted melting history. A small granitic dike that cross-cuts the outer portion of the Rupal shear yields monazite ages between $22 \mathrm{Ma}$ and $9 \mathrm{Ma}$, where the young ages correlate with high $\mathrm{U}$ concentrations. ${ }^{40} \mathrm{Ar}-{ }^{39} \mathrm{Ar}$ biotite ages from adjacent gneisses indicate cooling by $10 \mathrm{Ma}$, requiring significant displacement on this portion of the Rupal shear to be older than $\sim 10 \mathrm{Ma}$ and possibly as old as $\sim 20 \mathrm{Ma}$. (c) 1999 Elsevier Science B.V. All rights reserved.
\end{abstract}

Keywords: granites; Himalayas; geochronology

\section{Introduction}

Leucogranites in the central Himalayan orogen have received a surge of attention from geochronologists and geologists relying on the $\mathrm{U}-(\mathrm{Th})-\mathrm{Pb}$ technique on accessory minerals (e.g., monazite and

\footnotetext{
*Corresponding author. Tel.: +1-610-758-3660; Fax: +1-610758-3677; E-mail: dasd@lehigh.edu

${ }^{1}$ Present address: Department of Geology, University of Würzburg, Würzburg, Germany.
}

zircon) for determining crystallization ages $([1,2]$ and refs. therein). Such minerals are suitable due their high closure temperatures and resistance to age resetting during anatexis [3-5]. Mapping and geochronologic results of these studies indicate two belts of granite plutons [1]. These are: (1) the High Himalayan leucogranites (e.g., Garwal, Manaslu, Makalu), which are adjacent to the Southern Tibetan detachment system and appear to have been largely emplaced between 24 and $19 \mathrm{Ma}$ [1]; and (2) the North Himalayan granites (north of the High 


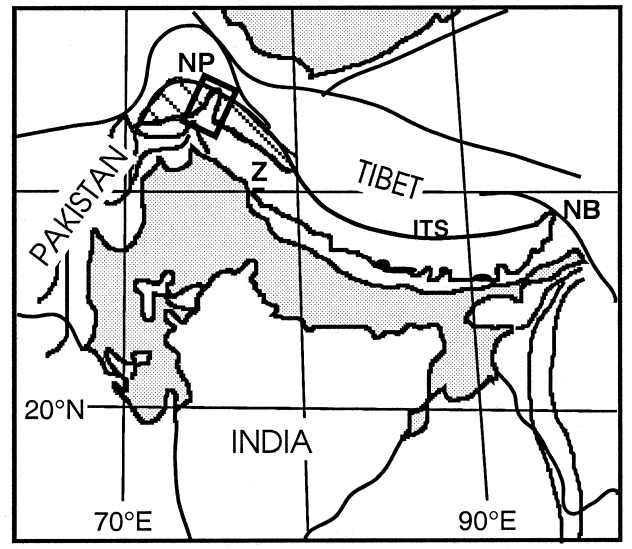

Fig. 1. Regional simplified tectonic map of the Himalaya [7]. $I T S=$ the Indus-Tsangpo Suture; $N B=$ Namche Barwa; $N P=$ Nanga Parabt; $Z=$ Zanskar. The cross-hatched pattern represents the Kohistan-Ladakh island arc and the stippled regions are foreland basins.

Himalayan belt), which were intruded into sedimentary rocks of the Tethyan Himalaya between 17 and $10 \mathrm{Ma}$ [1]. These Early to Middle Miocene granites have remained undisturbed by younger anatexis.

The Himalayan syntaxes are the terminations of the Himalayan belt and consist of recently unroofed migmatitic gneisses and uncommonly young magmatism (Fig. 1 [6-8]). Within Namche Barwa, at the eastern syntaxis, accessory mineral geochronology of leucosomes reveals crystallization ages as recent as 1.2 Ma [7]. Within the western syntaxis is Nanga Parbat, a crustal-scale pop-up structure $[9,10]$ with young leucogranites, whose crystallization ages young southward across the massif [11]. Melt stringers and meter-scale dikes yield U-(Th)$\mathrm{Pb}$ zircon and monazite ages between 7 and $5 \mathrm{Ma}$ in the northern and central portions of the massif [10,12] (D.A. Schneider unpubl. data) and between 3 and $1 \mathrm{Ma}$ in the summit region [8,11,12]. Larger, two-mica plutons (Fig. 2) give a similar age distribution: in the north, the Jutial pluton crystallized at $10 \mathrm{Ma}$ [13]; in the south, the Tato and Mazeno Pass plutons crystallized at $\sim 1$ and $1.4 \mathrm{Ma}$, respectively $[8,13]$. In addition to this general $<10 \mathrm{Ma}$ anatexis at Nanga Parbat, there is evidence in the northwest Himalaya for 50-45 Ma plutonism to the southwest of the massif [14]. However, there is no evidence in this portion of the Himalaya for the Early to Middle Miocene plutonism that is ubiquitous in the central portions of the Himalaya. The nearest previously reported example is a $20.0 \pm 0.5$ Ma pluton near Zanskar [15], $200 \mathrm{~km}$ southeast along the orogen. Miocene melting has also been recently documented in Asian plate rocks west of Nanga Parbat in the Hindu Kush [16]. We present the first report of Early Miocene plutonism in the western Himalaya syntaxis.

The Southern Chichi granite [17] is a largely undeformed, fine-grained leucogranite of several square kilometers located structurally in the footwall of the Rupal shear (Fig. 2), a major Nanga Parbat shear zone. The granite is undeformed except for a weak alignment of biotite close to its contact with the metasediments. It intrudes strained Indian cover metasediments including marbles, amphibolites and metapelites adjacent to the WNW-dipping Rupal shear zone. The shear zone is defined by monotonous granitic orthogneiss with ubiquitous $\mathrm{C} / \mathrm{S}$ fabric and augen asymmetry indicating dextral and NW-side-up displacement; prominent fabric stretching lineation plunges moderately to the south-southwest. The foliation of the adjacent metasedimentary sequences parallels, and does not appear to cut, the foliation within the shear zone orthogneiss. The metasedimentary rocks do not, however, show evidence for non-coaxial deformation, and do not appear to have taken up the prominent non-coaxial fabric of the granitic orthogneiss of the Rupal shear. Lineation in the metasedimentary rocks is defined by local crenulation intersection and axes of asymmetric, cmwavelength tight folds are also parallel with the nearby stretching lineation in the orthogneiss. The relationship, if any, between the granite and the $\mathrm{Ru}-$ pal shear is presently unclear due to inaccessibility of and ice cover in the region where they may intersect. Sample E7/9/21-II was taken from outcrop of the main body of the Southern Chichi pluton and dated in order to investigate timing of anatexis south of Nanga Parbat.

North of the Chichi pluton, within the Rupal shear, a very fine-grained biotite granite sheet crosscutting the foliation of the granitic orthogneiss was found preserved in float sample KC-9A. The location where this loose sample was found, the bed of a small side stream on the western wall of Chichi valley within the Rupal shear, is consistent with the bedrock source for this sample being nearby $(<1$ 


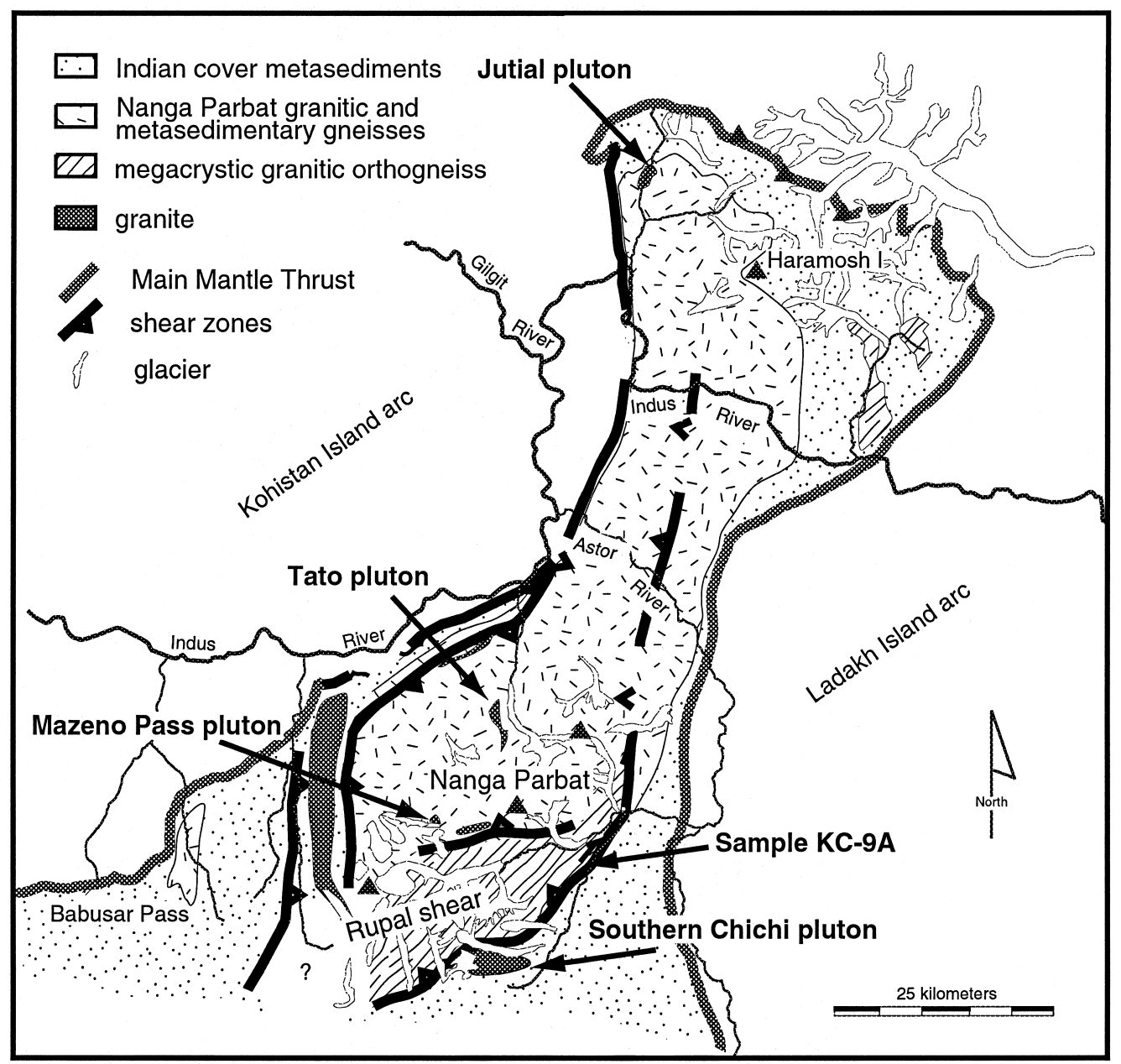

Fig. 2. Geologic map of the Nanga Parbat massif (after [10] and W.S.F. Kidd, M.A. Edwards, M.A. Khan and D.A. Schneider, unpubl. mapping) showing the location of the two granites sampled in this study and other dated plutons. Biotite samples discussed in text are in proximity to KC-9A.

$\mathrm{km})$ and up-slope. Petrographic examination confirms a lack of strain in the cross-cutting granite. We dated this granite hoping to determine the timing of cessation of deformation along the Rupal shear; a loose sample was used because it is at present the only example of a cross-cutting dike that we have found in orthogneisses of the outer Rupal shear zone.

\section{Results and discussion}

Monazite and zircon grains were separated from sample E7/9/21-II, mounted, polished and dated by the ${ }^{208} \mathrm{~Pb} /{ }^{232} \mathrm{Th}$ and $\mathrm{U} / \mathrm{Pb}$ ion microprobe method, respectively [18]; only monazite was obtained from sample KC-9A. The monazites from KC-9A and the Chichi granite are pale yellow and greenish-amber, respectively, and are all relatively anhedral. Zircons are rounded and clear, showing distinct inherited cores, confirmed by ion microprobe imaging. Ages are determined by direct reference to standards: (1) the zircon standard used is AS3 (UCLA) with an age of $1099 \pm 1 \mathrm{Ma}$; and (2) due to the high Th concentration in the unknowns, the two monazite standards which were used are 554 (UCLA), with an age of $45 \pm 1 \mathrm{Ma}$, and 4170 (GSC), with an age of $1836 \pm 1$ 

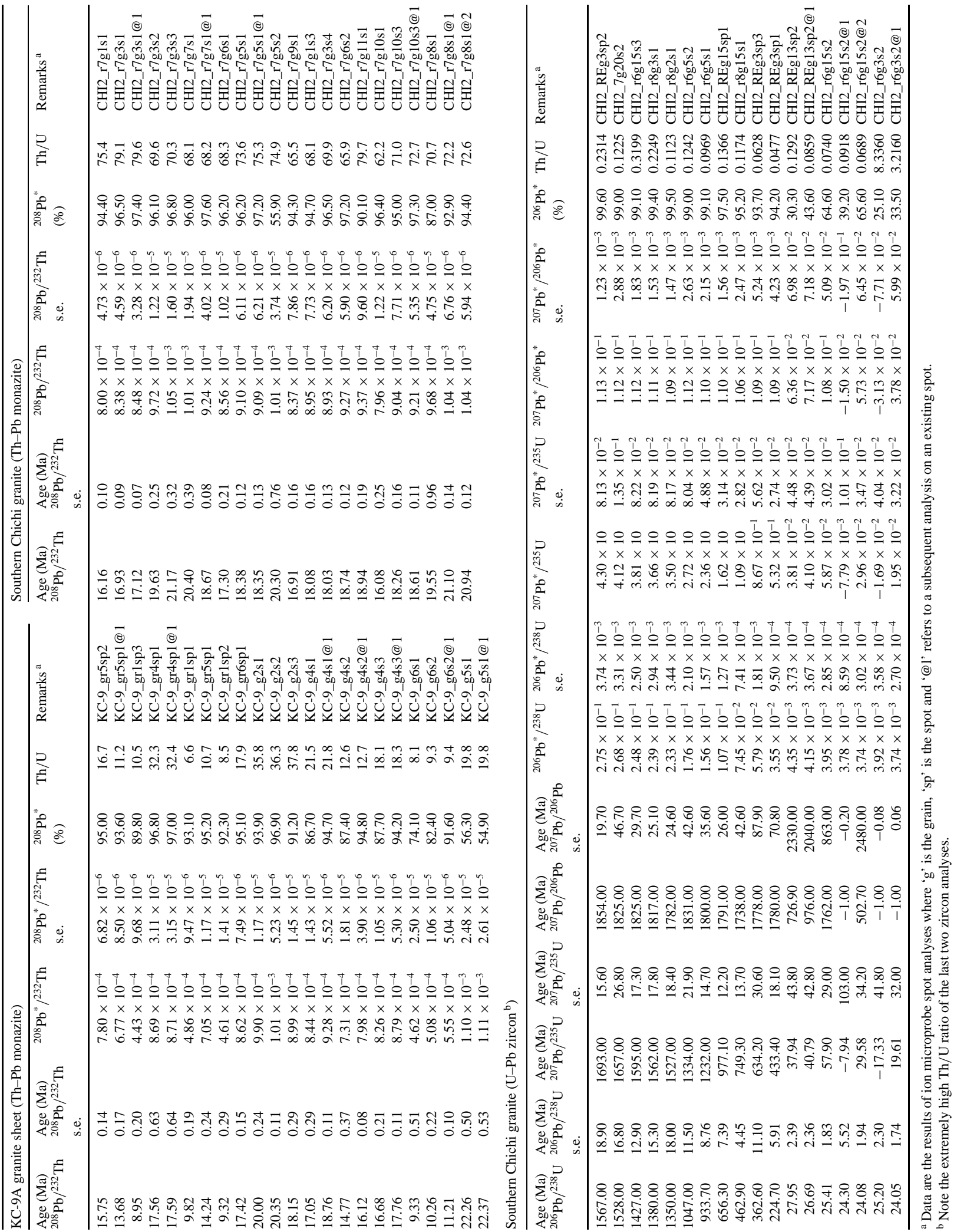
Ma and high (11-13\%) Th [19]. The latter standard is also a high-Th mineral and helped significantly in calibrating against our atypical unknowns. The reproducibility of the technique is typically $\pm 2 \%$ [18].

The Chichi granite is Early Miocene in age. $\mathrm{U} / \mathrm{Pb}$ zircon analyses (Fig. 3) yield ages that fall along a chord with an upper intercept age of $\sim 1850 \mathrm{Ma}$ which we regard as the same Precambrian protolith age that is seen elsewhere at Nanga Parbat in the re-worked gneisses and schists [11,20] and leucogranites $[8,13]$. Rim analyses yield apparently concordant ages of $24 \pm 1 \mathrm{Ma}$ and are not the high-U zircon rims seen typically throughout most of the Nanga Parbat leucogranite dikes [12,13]. However, repeat analyses on one spot $(\mathrm{g} 3 \mathrm{~s} 2, \mathrm{~g} 3 \mathrm{~s} 2 @ 1)$ yield anomalously high Th concentrations (Table 1) indicating the possibility of an inclusion within or a pseudomorph of zircon, so casting doubt on this spot age. Excluding these analyses from the concordia diagram and regression through all the remaining spot analyses yields a lower intercept of $19.1_{-6}^{+7}$ Ma. We believe that the zircon rims in all cases were smaller than actual ion microprobe beam size $(\sim 20 \mu \mathrm{m})$ and that we always sampled a fraction of the inherited core adjacent to the rim subsequently resulting in slightly older ages which are less than a few percent discordant. Furthermore, because trajectories of discordia are virtually coincident with the concordia curve which is almost a straight line for the $0-100$ Ma segment, these analyses appear concordant when plotted on a concordia diagram. This is in agreement with the higher than expected $\mathrm{Th} / \mathrm{U}$ ratios of the Early Miocene analyses indicating inheritance from the Paleoproterozoic cores.

The monazite ages are a bit enigmatic. $\mathrm{Th} / \mathrm{Pb}$ ion microprobe results of monazites from the Southern Chichi granite yield ages between 21 and 16 $\mathrm{Ma}$, with the majority of analyses lying at 19-18 Ma (Fig. 4) and a weighted mean monazite age of $19.1 \pm 1.53 \mathrm{Ma}$, consistent with the zircon dates. The monazite dates may simply be an artifact of binary mixing of two end members, $\sim 21$ and $\sim 16$ $\mathrm{Ma}$, or may represent a single magmatic episode ( $\sim 19$ Ma?) in which a number of primary and secondary processes influenced the monazite U-(Th)$\mathrm{Pb}$ dates (e.g., xenocrystic inheritance, $\mathrm{Pb}$ loss, hydrothermal growth, U-Th disequilibrium, deformation, etc.). Lead loss in the monazites due to subsequent metamorphism is not suspect since recent

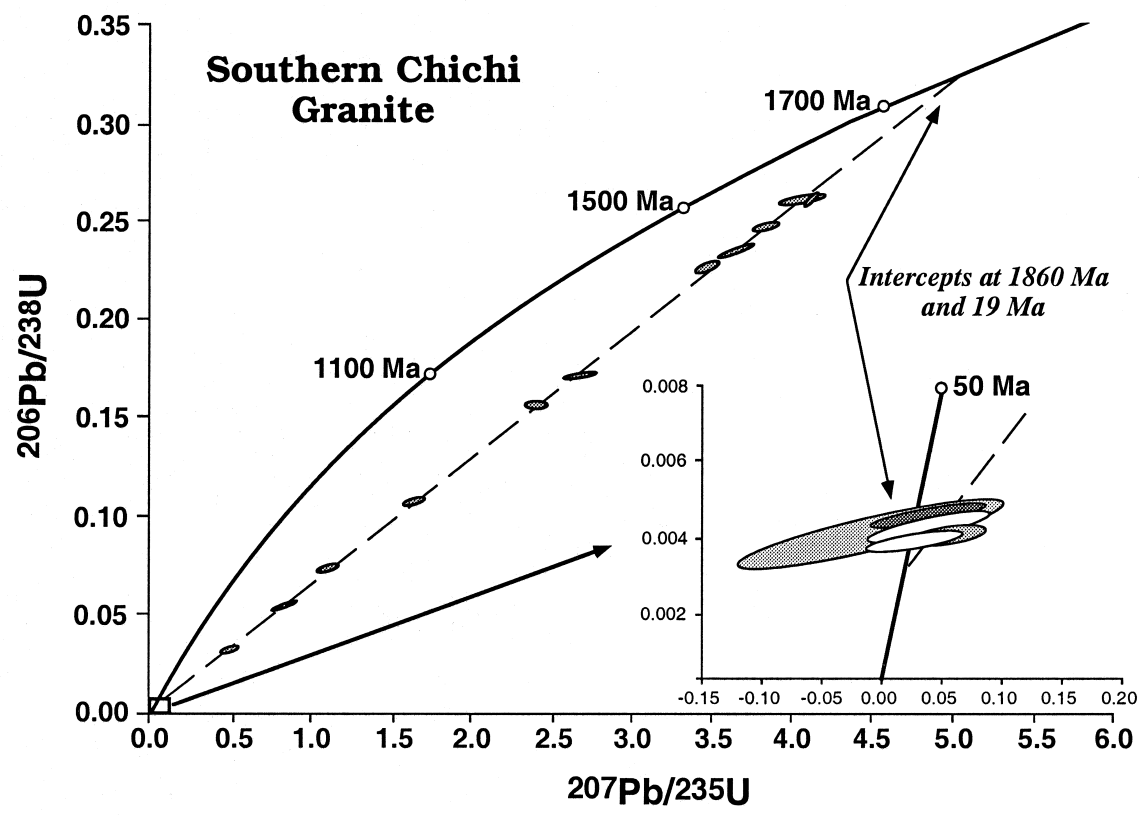

Fig. 3. U-Pb concordia plot showing zircon spot ages of the Chichi granite. Error ellipses are shown at the $2 \sigma$ level. Inset shows enlarged concordia origin. Shaded ellipses are for ease of viewing. 

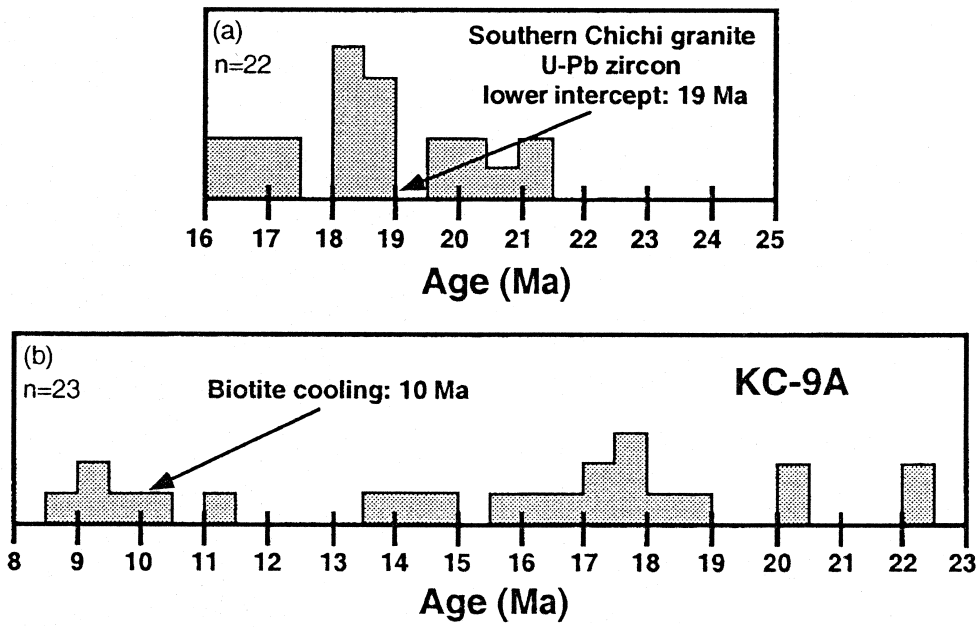

Fig. 4. Histogram of $\mathrm{Th}-\mathrm{Pb}$ ages obtained from the ion microprobe spot analyses of monazites from the Southern Chichi granite (a) and sample KC-9A, a granite sheet (b).

studies show that individual monazite grains do not allow significant $\mathrm{Pb}^{*}$ loss while at high temperature $[3,21]$. Furthermore, there appears to be no correlation between $\mathrm{Th}-\mathrm{Pb}$ age and elemental or isotopic concentration (Fig. 5), nor does there appear to be any significant correlation between analyses depth (sputtering depth) and anomalously high or low concentrations. There does, however, appear to be a slight common $\mathrm{Pb}$ contamination on the grain mount surface which disappears with sputtering depth.

Of recent interest in accessory mineral geochronology is the role that fluids play on the $\mathrm{U}-(\mathrm{Th})-\mathrm{Pb}$ systematics. Experimental studies of monazite growth on grain boundaries indicate that complex replacement zones grow from aqueous fluids [22] and further hydrothermal fluid interaction results in lead loss in monazites well below their closure temperatures through a dissolutionprecipitation process [23]. During this process, $\mathrm{Pb}$ is not incorporated into the newly grown monazites and remains in the fluid phase. In contrast, all of the $U$ is reincorporated into the solid and no significant amounts of $U$ are partitioned into the fluid. Subsequently, the $\mathrm{Pb}$ distribution within relict old and newly grown grains is inhomogeneous resulting in a monazite system consisting of undisturbed portions along with rejuvenated neogrowth [23]. This is markedly different from $\mathrm{Pb}$ loss via hydrothermal leaching which is limited to the surface of
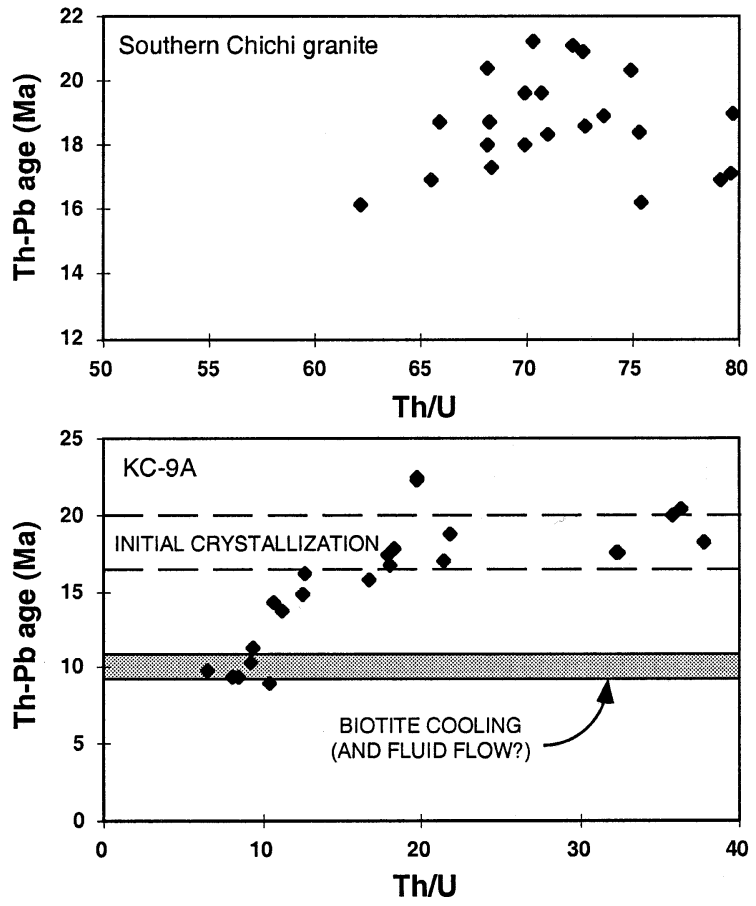

Fig. 5. Plot of $\mathrm{Th} / \mathrm{U}$ ratio vs. Th-Pb age for both analyzed granites. No pattern exists in the Southern Chichi granite, but a strong correlation is present in KC-9A and the younger monazite ages are coincident with the biotite cooling ages.

the grain [23]. Consequently, recrystallization or related processes may have controlled relative retention among minerals that were subjected to perva- 
sive, post-growth hydrothermal fluid infiltration [24]. In Nanga Parbat, fluid migration paths typically exploit the shear zones $[25,26]$; this presents a strong case for fluid-mineral interaction within the Chichi granite which lies adjacent to the Rupal shear. We do submit the possibility that these monazites may have been altered by hydrothermal fluids for which Nanga Parbat is known.

Nevertheless, because our zircon rims are not high-U, we feel that they are not hydrothermally deposited and are true magmatic rims; the concordancy between our $\mathrm{U}-\mathrm{Pb}$ ages and the majority of $\mathrm{Th}-\mathrm{Pb}$ ages leads us to assign a best crystallization age estimate of $19 \mathrm{Ma}$ for the Southern Chichi granite, considerably older than the recent metamorphic events at Nanga Parbat. A xenocrystic component and/or hydrothermal alteration may cause the apparent spread of monazite ages which is seen in numerous rocks of a variety of ages: Paleoproterozoic [27], Paleozoic [28], and Mesozoic and Cenozoic $[29,30]$.

Monazite spot analyses from the cross-cutting granite, KC-9A, yield a spread of $\mathrm{Th}-\mathrm{Pb}$ ages between 22 and $9 \mathrm{Ma}$ (Fig. 4). Unlike the Chichi granite, there does appear to be a correlation between age and $\mathrm{Th} / \mathrm{U}$ ratio which reflects a higher $\mathrm{U}$ concentration with younger ages (Fig. 5). Studies in the Canadian Cordillera and Nepal Himalaya indicate that the $\mathrm{U}$ concentration can exert an important control on $\mathrm{Pb}$ retentivity of accessory minerals [29,30]. Minerals with very high $U$ concentrations inevitably yield a spread of ages with the actual crystallization age being the older dates. Cogenetic grains which lose some component of their $\mathrm{Pb}^{*}$ immediately following crystallization will retain concordant $\mathrm{U}-(\mathrm{Th})-\mathrm{Pb}$ compositions, but will differ in age from neighboring grains depending on size and U concentration [29].

Multigrain laser ${ }^{39} \mathrm{Ar} /{ }^{40} \mathrm{Ar}$ analyses were performed on biotites (Table 2) from three separate samples of dike-adjacent gneisses and suggest cooling around $10 \mathrm{Ma}$. These ages overlap with the youngest monazite ages (Fig. 5) which constrains the minimum age of the granite sheet and minimum age for shear zone to $10 \mathrm{Ma}$, and the older monazite ages may indicate an inheritance of an Early Miocene source. However, if higher U concentrations give erroneous young ages or the young ages represent products of the hydrothermal dissolutionprecipitation process, we then must invoke an age of 20-17 Ma for the initial crystallization of the granite sheet, giving a maximum age of the granite sheet and the shear zone. In any case, we have constrained the age of the outer portion of the Rupal shear to between 10 and $20 \mathrm{Ma}$, again much older than typical Nanga Parbat structures.

\section{Conclusion}

The Early Miocene age of the Southern Chichi granite and the small granite dike is surprising in view of the otherwise exclusive presence of $<10$ Ma plutonism and metamorphism in this area. Our new $\mathrm{U}-(\mathrm{Th})-\mathrm{Pb}$ isotopic data place significant new constraints on the timing of crustal anatexis and deformation in the western syntaxis, and two main implications are discussed below.

(1) The 22-9 Ma crystallization age of the small dike that cuts the Rupal shear zone and biotite thermochronology within the shear zone requires that principal ('ductile') displacement on the local portions of the shear zone ceased prior to at least $\sim 10$ Ma. This is surprising in view of our previously reported geochronological and structural evidence that the Rupal shear zone is associated with the recent unroofing of the Nanga Parbat massif (e.g., very young cross-cutting dikes (1-2 Ma) and mica cooling ages $(<5 \mathrm{Ma})$ in the northern parts of the Rupal shear

Table 2

Multigrain laser fusion ${ }^{40} \mathrm{Ar} /{ }^{39} \mathrm{Ar}$ biotite age

\begin{tabular}{|c|c|c|c|c|c|c|c|c|c|c|c|c|c|c|}
\hline Sample & $\begin{array}{l}\text { Age } \\
\text { (Ma) }\end{array}$ & s.e. & $40 / 39$ & $\begin{array}{l}\text { Error } \\
(\%)\end{array}$ & $38 / 39$ & $\begin{array}{l}\text { Error } \\
(\%)\end{array}$ & $37 / 39$ & $\begin{array}{l}\text { Error } \\
(\%)\end{array}$ & $36 / 39$ & $\begin{array}{l}\text { Error } \\
(\%)\end{array}$ & $\begin{array}{l}{ }^{39} \mathrm{Ar} \\
(\mathrm{mol})\end{array}$ & $\begin{array}{l}\text { Error } \\
(\%)\end{array}$ & $\begin{array}{l}{ }^{40} \mathrm{Ar}^{*} \\
(\%)\end{array}$ & ${ }^{40} \mathrm{Ar}^{*} /{ }^{39} \mathrm{ArK}$ \\
\hline CHS-6 & 10.33 & 0.14 & 38.011 & 0.219 & 0.042 & 0.449 & 0.003 & 3.063 & 0.067 & 0.784 & $2.85 \times 10^{-15}$ & 0.0022 & 47.49 & 18.05 \\
\hline CHS-4 & 11.25 & 0.12 & 30.379 & 0.199 & 0.03 & 0.544 & 0.005 & 1.769 & 0.036 & 0.764 & $3.02 \times 10^{-15}$ & 0.0019 & 64.73 & 19.66 \\
\hline CHS-1 & 9.83 & 0.77 & 23.153 & 4.433 & 0.069 & 3.626 & 0.085 & 5.432 & 0.02 & 16.3 & $1.02 \times 10^{-14}$ & 0.0265 & 74.19 & 17.18 \\
\hline
\end{tabular}


zone in the summit region of the massif $[9,11])$. Based upon our new data, we propose that displacement has not occurred concurrently across the entire Rupal shear, but has migrated into the Nanga Parbat massif as deformation progressed, from $>10 \mathrm{Ma}$ in the outer shear zone to $<2 \mathrm{Ma}$ in the inner (northern) shear zone. This is consistent with a general 'inward' younging of plutonism and cooling that we previously described for the massif [11].

(2) The Chichi granite, as well as the small granite dike, represents an Early Miocene end-product of partial melting of Indian plate protolith. The Early Miocene age of the Southern Chichi granite is comparable with other granites in the central portion of the Himalaya, and we infer that the Miocene melting that is ubiquitous in the High Himalaya can now be conclusively extended $\sim 200 \mathrm{~km}$ westward to Nanga Parbat. We remark that the apparent absence of earlier melting at the massif is due to large exhumation and deep crustal reworking obscuring and obliterating the Early Miocene evidence in the inner portions of the massif. This investigation has prevailed sufficiently southwards to pass into the portion where main High Himalayan events can now be recognized. We speculate that our Miocene ages reflect the same 24-19 Ma period of crustal anatexis in the Himalaya identified in southern Tibet and Nepal [1]. Moreover, we note that the massif has undergone anatexis as recently as $\sim 1 \mathrm{Ma}[8,13]$, and conclude that the western syntaxis has a protracted tectonic history with at least two major periods of activity: (1) Early Miocene anatexis, and (2) late Neogene to Quaternary anatexis and deformation. A similar scenario may also be applicable in the eastern Himalaya syntaxis.

\section{Acknowledgements}

Supported by US National Science Foundation grants EAR 9418849 to PKZ, and EAR 9418730 to WSFK as part of the Nanga Parbat Continental Dynamics Project 'Crustal re-working during orogeny'. The ims 1270 Microprobe Facility at UCLA is supported in part by a grant from the NSF Instrument Facilities Program. Thanks to Robert Stern of the Geological Survey of Canada for supplying monazite standard 4170. [CL]

\section{References}

[1] T.M. Harrison, O. Lovera, M. Grove, New insights into the origin of two contrasting Himalayan granite belts, Geology 25 (1997) 899-902.

[2] M. Searle, Cooling history, erosion, exhumation and kinematics of the Himalaya-Karakorum-Tibet orogenic belt, in: A. Yin, T.M. Harrison (Eds.), Tectonics of Asia, Cambridge Univ. Press, Cambridge, 1996, pp. 110-137.

[3] R. Parrish, U-Pb dating of monazite and its application to geological problems, Can. J. Earth Sci. 27 (1990) 14311450.

[4] S. Inger, N. Harris, Geochemical constraints on leucogranite magmatism in the Langtang Valley, Nepal Himalaya, J. Petrol. 23 (1993) 234-247.

[5] J. Lee, I.S. Williams, D. Ellis, Pb, U, Th diffusion in natural zircon, Nature 390 (1997) 159-161.

[6] D.N. Wadia, Notes on the geology of Nanga Parbat (Mt Diamir) and adjoining portions of Chilas, Gilgit district, Kashmir, Rec. Geol. Soc. India 66 (1932) 212-234.

[7] J.P. Burg, P. Davy, P. Nievergelt, F. Oberli, D. Seward, Z. Diao, M. Meier, Exhumation during crustal folding in the Namche Barwa syntaxis, Terra Nova 9 (1997) 117-123.

[8] P. Zeitler, C.P. Chamberlain, H. Smith, Synchronous anatexis, metamorphism, and rapid denudation at Nanga Parbat, Pakistan Himalaya, Geology 21 (1993) 347-350.

[9] M. Edwards, W. Kidd, L. Seeber, A. Pêcher, P. Le Fort, M. Riaz, M.A. Khan, An upwardly mobile indentor? The Nanga Parbat-Haramosh Massif viewed as a crustal-scale pop-up structure, Eos 236 (1996) F692.

[10] D. Schneider, M. Edwards, W. Kidd, M.A. Khan, A. Pêcher, P. Le Fort, L. Seeber, P. Zeitler, C. Coath, Active tectonics of Nanga Parbat, western Himalaya: synkinematic plutonism within the doubly-vergent shear zones of a crustal scale pop-up structure, Science (submitted).

[11] D. Schneider, P. Zeitler, M. Edwards, W. Kidd, Geochronological constraints on the geometry and timing of anatexis and exhumation at Nanga Parbat: a progress report, Eos 78 (1997) S312.

[12] P. Zeitler, C.P. Chamberlain, Petrogenetic and tectonic significance of young leucogranites from the NW Himalaya, Pakistan, Tectonics 10 (1991) 729-741.

[13] D. Schneider, M. Edwards, W. Kidd, P. Zeitler, C. Coath, Mazeno Pass pluton and Jutial Pluton, Pakistan Himalaya: age and implications for entrapment mechanisms of two granites in the Himalaya, Contrib. Mineral. Petrol. (submitted).

[14] H. Smith, C.P. Chamberlain, P. Zeitler, Timing and duration of Himalayan metamorphism within the Indian plate, northwest Himalaya, Pakistan, J. Geol. 102 (1994) 493508.

[15] S. Noble, M. Searle, Age of crustal melting and leucogranite formation from $\mathrm{U}-\mathrm{Pb}$ zircon and monazite dating in the western Himalaya, Zanskar, India, Geology 23 (1995) $1135-1138$.

[16] P. Hildebrand, S. Noble, M. Searle, R. Parrish, Shakirul- 
lah, Tectonic significance of $24 \mathrm{Ma}$ crustal melting in the eastern Hindu Kush, Pakistan, Geology 26 (1998) 871-874.

[17] M.A. Edwards, Examples of Tectonic Mechanisms for Local Contraction and Exhumation of the Leading Edge of India, Southern Tibet and Nanga Parbat, Pakistan. PhD Dissertation, State University of New York at Albany, 1998, 308 pp.

[18] T.M. Harrison, K. McKeegan, P. Le Fort, Detection of inherited monazite in the Manaslu leucogranite by ${ }^{208} \mathrm{~Pb} /{ }^{232} \mathrm{Th}$ ion microprobe dating: crystallization age and tectonic implications, Earth Planet. Sci. Lett. 133 (1995) 271-282.

[19] R. Stern, N. Sanborn, 1998. Monazite U-Pb and Th$\mathrm{Pb}$ geochronology by high-resolution secondary ion mass spectrometry (SHRIMP), Radiogenic age and isotope studies, Report 11, GSC, Current Research 1998-F.

[20] P. Zeitler, J. Sutter, I.S. Williams, R.E. Zartman, R.A.K. Tahirkheli, Geochronology and temperature history of the NPHM, Pakistan, in: L.L. Malinconico, R.J. Lillie (Eds.), Tectonics of the Western Himalayas, Geol. Soc. Am. Spec. Pap. 232 (1989) 1-23.

[21] M. Edwards, T.M. Harrison, When did the roof collapse? Late Miocene north-south extension in the high Himalaya revealed by $\mathrm{Th}-\mathrm{Pb}$ monazite dating of the Khula Kangri granite, Geology 25 (1997) 543-546.

[22] J.C. Ayers, C.F. Miller, How do monazite and zircon grow, and what do monazite and zircon $\mathrm{U}-\mathrm{Pb}$ age dates mean? Insights obtained from experiments, Geol. Soc. Am. Abstr. Progr. A214 (1998).

[23] S. Teufel, W. Heinrich, Partial resetting of the U-Pb isotope system in monazite through hydrothermal experiments: a
SEM and U-Pb isotope study, Chem. Geol. 137 (1997) 273-281.

[24] P.S. Dahl, A crystal-chemical basis for $\mathrm{Pb}$ retention and fission-track annealing systematics in U-bearing minerals, with implications for geochronology, Earth Planet. Sci. Lett. 150 (1997) 277-290.

[25] P. Chamberlain, P. Zeitler, D. Barnett, D. Winslow, S. Poulson, T. Leahy, J. Hammer, Active hydrothermal systems during the recent uplift of Nanga Parbat, Pakistan Himalaya, J. Geophys. Res. 100 (1995) 439-453.

[26] M. George, J. Bartlett, Rejuvenation of Rb-Sr mica ages during shearing on the northwestern margin of the Nanga Parbat-Haramosh massif, Tectonophysics 260 (1996) 167 185.

[27] D. Hawkins, S. Bowring, U-Pb systematics of monazite and xenotime: case studies from Paleoproterozoic of the Grand Canyon, Arizona, Contrib. Mineral. Petrol. 127 (1997) 87-103.

[28] A. Lanzirotti, G. Hanson, U-Pb dating of major and accessory minerals formed during metamorphism and deformation of metapelites, Geochim. Cosmochim. Acta 59 (1995) 2513-2526.

[29] R. Parrish, S. Carr, U-Pb problematics of very high-U accessory minerals: examples from the Himalaya and Cordillera and implications for U-Pb geochronology, ICOG Abstr. 8 (1994) 243.

[30] R. Parrish, K. Hodges, A. Macfarlane, U-Pb geochronology of igneous and metamorphic rocks near the Main Central Thrust in the Langtang area, central Nepal Himalaya, Himalaya-Karakorum-Tibet Workshop, 1992, Abstr. 7, pp. 67-68. 